Review Article

www.ijrap.net

\title{
INDIAN AYURVEDIC AND TRADITIONAL MEDICINAL IMPLICATIONS OF INDIGENOUSLY AVAILABLE PLANTS, HERBS AND FRUITS: A REVIEW
}

\author{
Subha Ganguly* \\ AICRP On Post Harvest Technology (ICAR), Department of Fish Processing Technology, Faculty of Fishery Sciences, \\ West Bengal University of Animal and Fishery Sciences, 5, Budherhat Road, P.O. Panchasayar, Chakgaria, \\ Kolkata 700 094, WB, India
}

Received on: 12/05/13 Revised on: 28/06/13 Accepted on: 14/07/13

\author{
*Corresponding author \\ E-mail: ganguly38@gmail.com \\ DOI: 10.7897/2277-4343.04435 \\ Published by Moksha Publishing House. Website www.mokshaph.com \\ All rights reserved.
}

\section{ABSTRACT}

The importance of various herbal ingredients and plant derivatives in immunomodulation is a subject for scientific investigations currently worldwide. The mystery of Moringa oleifera as a vegetable source for immunomodulation in human and its capacity to impart protection against diseases by building host resistance has made it an important and economical nutritional supplement majorly in developing countries. The coconut fruit obtained from the coconut palm has numerous medical and commercial benefits. The various health related properties of coconut water, coconut milk, coconut cream, creamed coconut and other derivatives from the fruit have been highlighted in this article. The abstract provides an overall summary of different utilities and profile of different products obtained from the coconut for which it is being used as a principal ingredient by almost every consumer in Asian and Western countries in cooking and eating practices. The various derivatives from the fruit are well acceptable to consumers of all age groups, having certain limitations its high saturated fat content. Coconut has been recently proved to be a source of saturated fat that would not elevate the lipid profile in the body, except High Density Lipoprotein (HDL), which is good for health and absolutely no contraindications now to any age. Coconut is a highly valued ingredient in our eating practice for its enormous medical benefits. However, due to its high lipid and saturated fat content it is discouraged in the diet of patients suffering from cardiovascular ailments and hypertension. The major importance of the fruit is valued for the great medicinal properties of coconut water and the flesh of the fruit. The meat of mature coconut is a flavoring and texture improving ingredient in Indian and Asian homemade food. Lime is having tremendous importance in our diet and regular feeding habits due to its enormous nutritional and natural medicinal benefits from ancient time in India. It keeps away many diseases, improves resistance to diseases and provides long term profits by purifying blood in the body system naturally. The present review has been constructed considering the future scope of research in immunomodulation in medical and veterinary sciences which can be explored from the different vegetative resources available naturally to us.

Keywords: Medicinal plants, Herbal extracts, Fruit.

\section{INTRODUCTION}

Many herbal plant preparations are prescribed to strengthen host resistance. ${ }^{1,2}$ Many useful plants fall under this category. They exhibit immunomodulatory activities. One such plant, Tinospora cordifolia, commonly called 'Guduchi' has been examined for its immunomodulatory properties. Guduchi means to rejuvenate dead cells. It is widely used in veterinary folk medicine and has also been claimed to be beneficial according to 'Ayurveda' for the cure of jaundice, skin diseases, diabetes, anemia, emaciations and various infections for its anti-spasmodic, anti-inflammatory, anti-arthritic and anti-allergic properties. ${ }^{3}$ It has also been reported that it improves the phagocytic and bactericidal activities in patients suffering from polymorphism in surgical jaundice. ${ }^{2}$ Kolte et al. ${ }^{4}$ studied the effect of feeding Tinospora cordifolia in broiler birds which were immunosuppressed with cyclophosphamide. They had found a significant rise in antibody titer against ND virus with augmentation of inflammatory reaction to skin contact sensitivity test. Rege et al. ${ }^{5,6}$ and Bishavi et $a l^{7}{ }^{7}$ have proved the hepatoprotective effect of Tinospora cordifolia. Manjrekar et $a^{8}{ }^{8}$ also found that aqueous extract of Tinospora cordifolia is capable of increasing leukocyte count in mice. Also, Ocimum sanctum, commonly known as 'tulsi' is also used in Ayurveda for various ailments including treatment of allergies. The plant has been reported to evince significant anti-stress properties. The beneficial effects of Ocimum sanctum could therefore be due to its direct or indirect effect on the immune system. Ocimum sanctum has been reported to modulate humoral immune response by releasing mediators for hypersensitivity reactions. ${ }^{9-11}$ Withania somnifera also fall in this category with many other useful plants. They exhibit immunomodulatory activities. Withania somnifera (commonly called 'Ashwagandha') root extracts possess anti-estrogenic, adaptogenic, anti-cancer and anabolic activities having beneficial effects in the treatment of arthritis, geriatric problems and stress. The root of Asparagus racemosus (commonly called 'Satavar') possess anti-diarrheal, anti-ulcerative, anti-spasmodic, aphrodisiac, galactogogue and other properties and has therefore gained its importance in Ayurveda, Siddha and Unani systems of medicine. ${ }^{12}$ It has been observed that feeding Withania somnifera and Asparagus racemosus dried root powder significantly stimulates both humoral and cell mediated immune responses in swiss albino mice by Kuttan and Kuttan ${ }^{13}$. Withania somnifera and Asparagus racemosus extracts increase phagocytic activities of macrophages in vitro. ${ }^{14}$ Moringa oleifera is a highly valued plant, distributed in many countries of the tropics and subtropics. Moringa is nature's medicine cabinet. It is best known as excellent source of nutrition and a natural energy booster. Different parts of this plant are being employed for the treatment of different ailments in the indigenous system of medicine. The plant has 
tremendous pharmacological action and pharmaceutical application too. It possesses analgesic, anti-inflammatory, antipyretic, anti-asthmatic and wound healing properties. Also, it possesses anti-diabetic, anti-cancerous and hepatoprotective properties too. ${ }^{15,16}$

Extract from the seeds is used as a flocculant in a low cost form of water treatment. It effectively helps in bacterial reduction in edible water. The seeds are also considered an excellent biofuel source for making biodiesel. ${ }^{17}$

\section{Medicinal properties of Moringa oleifera}

Moringa leaves and pods are helpful in increasing breast milk in the breastfeeding months. One tablespoon of leaf powder provides $14 \%$ of the protein, $40 \%$ of the calcium, $23 \%$ of the iron and most of the vitamin A needs of 1-3 years aged children. Six tablespoons of leaf powder will provide nearly all of the woman's daily iron and calcium needs during pregnancy and breastfeeding. The Moringa seeds yield 38-40\% edible oil (called ben oil from the high concentration of behenic acid contained in the oil). The refined oil is clear and odorless and resists rancidity at least as well as any other botanical oil. The seed cake remaining after oil extraction may be used as a fertilizer or as a flocculent to purify water. The bark, sap, roots, leaves, seeds, oil and flowers are used in traditional medicine in several countries. ${ }^{14}$ The Moringa tree has great use medicinally both as preventative and treatment. Much of the evidence is anecdotal as there has been little actual scientific research done to support these claims. India's ancient tradition of Ayurveda says the leaves of the Moringa tree prevent 300 diseases. There have been reports on significant antibiotic activity of this tree. ${ }^{18}$

\section{Medicinal Value of coconut water}

Coconut water is considered to be sterile unless the fruit is damaged from an external source. There have been reports of coconut water used for intravenous administration where normal saline solution for medical purpose was unavailable in developing countries or on the war front. Coconut water is rich in mineral content with high potassium and anti-oxidant contents which has various medical utilities. Coconut water also contains cytokinin which is one of the beneficial components in it. ${ }^{19}$ Coconuts in which water to be used for drinking purpose are harvested from the coconut palms when they appear green in color. Coconuts sometimes due to natural calamities fell on the ground and they are susceptible to get damaged and get exposed for being damaged by insects or pests and animals. Coconut water acts as a natural energy or sports drink, as it is rich in mineral content especially in potassium levels. Coconut water has a high demand among consumers for its nil fat content and low contents of carbohydrates, calories and sodium. Coconut water serves as a potential healthy drink for adults and old persons as it has promising health utilities. ${ }^{19}$ Coconut milk has tremendous importance especially in Ayurvedic traditional medicinal purposes. It is generally used to maintain the electrolyte balance and to rule out dehydration losses. ${ }^{19}$ Also, it is used for treatment of ulcers in the mouth. ${ }^{20}$ Some recent studies have suggested that coconut milk has anti-microbial properties in the gastrointestinal tract, hyperlipidemic balancing qualities and useful for topical applications. ${ }^{19}$ In addition, the coconut milk contains auric acid as saturated fat which has medicinal utilities in the cardiovascular system. $^{21}$

\section{Medicinal utility of lime}

Limes are acidic in nature and serve as rich source of vitamin $\mathrm{C}$, citric acid, sugar, certain minerals like calcium and phosphorus. ${ }^{22}$ Fresh lime juice possess medicinal property which is well known from ancient ages in India. It is also called as sacred fruit in the Vedas, Sharangdhara and Charaka. The latter two famous physicians of ancient India had used the lime juice for alleviating orthopedic aliments therapeutically. ${ }^{22}$ The vitamin $\mathrm{C}$ as a primary component of the lime juice increases the resistance of individuals to several diseases, helps in wound healing and increases the health of eyes. It improves the maintenance of good dentition and keeps away toothache, dental caries, swollen gums, fragility of bones and bleeding of the gums. ${ }^{22,23}$ Lime is vital in the treatment of gastric disorders like indigestion, constipation and peptic ulcer. It stops the occurrence of indigestion, burning in the chest due to high acidity in the stomach, abrupt bilious vomiting and excessive accumulation of saliva in the mouth. Lime juice with a pinch of soda bicarb mixed in water improves indigestion and gastric upset due to severe acidity after heavy rich / spicy meals. It can also be used as carminative in indigestion and sedation is produced by release of carbonic acid and gas. In chronic constipation by promoting biliary secretion from the liver, it improves intestinal motility. ${ }^{23,24}$ The acidic juice of lime facilitates the lipid and alcohol absorption and neutralizes excessive bile produced by the liver. The juice reduces gastric acidity by counteracting with the effects of greasy food. It is, therefore, useful in the treatment of peptic ulcers. ${ }^{22}$ Acidic juice of the fruit acts as curative for tonsillitis. Oral ingestion of lime juice mixed with salt in water provides relief from burning sensation and also stops bleeding in cystitis (inflammation of urinary bladder). ${ }^{25}$ It is also a recommended therapy in weight reduction and in obesity. During mornings at empty stomach, lime juice with honey in lukewarm water to be ingested for 2-3 months for effective weight reduction. Of course, low calorie diet is also a must along with this. ${ }^{23}$

\section{Importance of other miscellaneous herbs and plants}

The plant derived and herbal growth promoters supplemented in the diet or added in the drinking water in the broiler and poultry birds have a promising biological effect on their growth performance, to reduce the pathogenic bacteriological load in different parts of digestive tract and to increase villus height in different segments of small intestine mainly in duodenum. The plant derived growth promoter enhance productive performance of the broiler in terms of body weight gain with minimum alteration of gut morphology and the possibility of bacterial invasion can be regulated. ${ }^{26-29}$

\section{CONCLUSION}

The present review summarizes the wide use of various plant extracts and herbal fed additives in a specific dose during the scheduled vaccination regimen. These plant 
extracts may be helpful in obtaining higher protective antibody against different infections including production and development of more effective cell mediate immune response for protection against various bacterial, viral and other diseases. Herbal formulation may be therefore recommended for use as positive immunomodulator in normal and immunocompromized susceptible animals and birds.

\section{REFERENCES}

1. Thatte UM, Dahanukar SA. Ayurveda and contemporary scientific thought. Trends Pharmacol Sci 1986; 17: 248-257.

2. Thatte UM, Dahanukar SA. Immunotherapeutic modification of experimental infection by Indian medicinal plants. Phytothe Res 1989; 3: 43-49. http://dx.doi.org/10.1002/ptr.2650030202

3. Prasad A, Ganguly S. Herbal Immunomodulators. AV Akademikerverlag GmbH and Co KG, Saarbrücken, Germany with trademark LAP LAMBERT Academic Publishing; 2012. ISBN 9783-659-30401-9.

4. Kolte AY, Siddiqui MF, Mode SG. Immunomodulating effect of Withania somnifera and Tinospora cordifolia in broiler birds; 2007.

5. Rege NN, Dahanukar SA. Quantitation of microbicidal activity of mononuclear phagocytes: an in vitro technique. J. Postgrad Med 1993; 39(1): 22-25. PMid:8295140

6. Rege NN, Nazareth HM, Bapat RD, Dhanukar SA. Modulation of immunosuppression in obstructive jaundice by Tinospora cordifolia. Indian J Med Res 1989; 90: 478-83. PMid:2697692

7. Bishavi B, Roychowdhury S, Ghosh S, Sengupta M. Hepatoprotective and immunomodulatory properties of Tinospora cordifolia in $\mathrm{CCl}_{4}$ intoxicated mature albino rats. J Toxicol Sci 2002; 27(3): 139-46. http://dx.doi.org/10.2131/jts.27.139

8. Manjrekar PN, Jolly CI, Narayan S. Comparative studies of the immunomodulatory acivities of Tinospora cordifolia and Tinospora sinensis. Fitoterapia 1999; 71: 254-57. http://dx.doi.org/10.1016/ S0367-326X(99)00167-7

9. Krishnamohan AV, Reddy DB, Sarma B, John Kirubharan J. Studies on the effects of levamisole against Newcastle disease virus in chicken. Indian J Comp Microbiol Immunol Infect Dis 1997; 8: $1-6$.

10. Kujur RT. Evaluation of certain immunomodulatory agents in countering immunosuppressive effects of vaccine strain of infectious bursal disease virus in chicks; 2001. MVSc thesis. Rajendra Agricultural Univ., Bihar, India.

11. Kumar P. Studies on comparative immunomodulatory effect of herbal preparation and Vitamin E-Se in comparison to Levamisole in broiler chicks; 2003. MVSc thesis. Birsa Agricultural Univ., Ranchi, India.

12. Nadkarni AK. Indian Materia Medica. Popular Book Depot, Bombay. $3^{\text {rd }}$ ed. $1954 ; 1: 153-55$

13. Kuttan G, Kuttan R. Immunomodulatory activity of a peptide isolated from Viscum album extract. Immunol Invest 1992; 21: 28596. http://dx.doi.org/10.3109/08820139209069368 PMid:1398778

14. Ganguly S and Prasad A. Role of plant extracts and cow urine distillate as immunomodulator in comparison to levamisole- a Review. J Immunol Immunopathol 2010; 12(2): 91-94
15. Aney JS, Tambe R, Kulkarni M, Bhise K. Pharmacological and Pharmaceutical Potential of Moringa oleifera: A Review. Journal of Pharmacy Research 2009; 2(9):1424-26.

16. Prasad A, Ganguly S. Promising medicinal role of Moringa oleifera: A Review. J Immunol Immunopathol 2012; 14(1): 1-5. http://dx.doi.org/10.5958/j.0972-0561.14.1.001

17. Michael L. Bioremediation of Turbid Surface Water Using Seed Extract from Moringa oleifera Lam. Drumstick Tree; 2010. http://dx.doi.org/10.1002/9780471729259.mc01g02s16

18. Akhouri S, Prasad A, Ganguly S. Moringa oleifera leaf extract imposes better feed utilization in broiler chicks. J Biol Chem Res 2013; 30(2): 447-50.

19. Ramachandran C, Peter KV, Gopalakrishnan PK. Drumstick Moringa oleifera: A multipurpose Indian Vegetable. Economic Botany 1980; 34(3): 276-83. http://dx.doi.org/10.1007/BF02858648

20. Ganguly S. Health benefits of coconut in the Asian cuisines: A Review. J Biol Chem Res 2013a; 30(2): 517-21.

21. Nneli RO, Woyike OA. Anti-ulcerogenic effects of coconut Cocos nucifera extract in rats. Phytother Res 2008; 22: 970-72. http://dx.doi.org/10.1002/ptr.2318 PMid: 18521965

22. Mensink, Ronald P, Peter L Zock, Arnold DM Kester and Martijn B Katan. Effects of dietary fatty acids and carbohydrates on the ratio of serum total to HDL cholesterol and on serum lipids and apolipoproteins: a meta-analysis of 60 controlled trials. American Journal of Clinical Nutrition, American Society for Clinical Nutrition 2003; 77(5): 1146-55.

23. Ganguly S. Medicinal properties of lime and its traditional food value. Res J Pharm Sci 2013b; 2(4): 19-20.

24. Room Adrian. A dictionary of true etymologies, Taylor and Francis; 1986. p. 101

25. Raichlen Steven. Small citruses yield tart juice, aromatic oils, big fresh taste; 1992. The Baltimore Sun.

26. Ganguly S. Herbal and plant derived natural products as growth promoting nutritional supplements for poultry birds: A Review. J Pharm Sci Innov 2013c; 2(3): 12-13. http://dx.doi.org/10.7897/ 2277-4572.02323

27. Ganguly S. A Handbook on Traditional Medicinal Plants, Herbs and Fruits in Indian Agriculture and Forestry. $1^{\text {st }}$ ed. International EPublication; 2013d. ISBN 978-81-927544-5-1. Official e-Book, Section: Agriculture and Forestry Sciences publication of the International Science Congress Association, Indore, UP, India.

28. Banerjee S, Mukhopadhayay SK, Haldar S, Ganguly S, Pradhan S, Patra S, Niyogi D, Isore DP. Effect of phytogenic growth promoter on broiler birds. J Pharmacogn Phytochem 2013a; 1(6): 183-88.

29. Banerjee S, Mukhopadhayay SK, Ganguly S. Phytogenic growth promoter as replacers for antibiotic growth promoter in poultry birds. J Anim Genet Res 2013b; 1(1): 6-7, http://dx.doi.org /10.12966/jagr.05.02.2013

\section{Cite this article as:}

Subha Ganguly. Indian Ayurvedic and traditional medicinal implications of indigenously available plants, herbs and fruits: A review. Int. J. Res. Ayurveda Pharm. 2013;4(4):623-625 http://dx.doi.org/10.7897/2277$\underline{4343.04435}$ 